\section{"Stuck in the muck": an eco-idiom of distress from childhood respiratory diseases in an urban mangrove in Northeast Brazil}

\author{
"Atolado na lama": ecoidioma de sofrimento com \\ doenças respiratórias infantis em um manguezal \\ urbano do Nordeste do Brasil
}




\section{Introduction}

In Northeast Brazil, with its booming capitalist economy, rapid disordered growth, and new imperfect democracy, respiratory diseases threaten children's lives 1, as in other globalizing regions 2. In Fortaleza (pop. 2.4 million) in 2005, $46.1 \%$ of public hospital admissions of children less than four years of age were due to respiratory conditions; $90 \%$ of these were for pneumonia (DATASUS. Informações de saúde 2006. http://www2.datasus.gov.br/DATASUS/index. php?area $=02$, accessed on $17 / \mathrm{Jul} / 2006$ ). Cyclical droughts in the state's interior have fueled migration to the capital, causing its 83 shantytowns (favelas) in 19723 to swell to 317 by 2010 (IBGE. Censo Demográfico 2010. Aglomerados subnormais. http://www.ibge.gov.br, accessed on $05 / J u l / 2012$ ). Recent migrants crowd into impoverished slums like Gato Morto (literally "Dead Cat"), Favela do Rato ("Rat Slum"), and Jangurussu, a resettlement community on the periphery of a garbage dump. The poorest of the poor, some 69,000 families in 2004, are squeezed into "risk areas" 4, including polluted soggy mangroves castigated by downpours, flash floods, and inundations during the rainy season.

Amidst such human misery, disease control efforts appear woefully inadequate. The World Health Organization's "integrated management of childhood illnesses" 5 prioritizes a disease-based paradigm ${ }^{6}$. According to Capra 6 , the hegemonic biomedical model - focusing on malfunctioning organs and intercellular pathological processes - reduces and fragments the more variegated human experience. Behavior cannot be isolated from its context, nor can determinants be untangled from webs of causality 7,8,9. A human calculus of infection is missing. The (re)emergence of ecological models of disease and misfortune 10,11,12,13 offers an amplified socio-ecological perspective on reality. This holistic model, by contrast, contextualizes complex disease determinants, captures all-encompassing risky contexts, and embeds subjective illness narratives within a particular ecosystem and moral world 7,8,9.

Despite the truism according to which "place affects health", few authors have theoretically linked individual agency to social structure. An exception is French sociologist Pierre Bourdieu 14,15. Bourdieu's conceptualizations of "social space", "habitus", and "symbolic violence" reconcile internal subjective experience with external structural features. Given life's uncertainties, there are literally infinite macro-structural forces operating in any particular place. By situating them in their "social space", factors shaping health attitudes and actions can be identified. Indeed,
Bourdieu sees ordinary people as resourceful "strategists" 14,15 who proactively "move through a maze of constraints and opportunities that they grasp imperfectly through past experiences and over time" (p. 80-1) 13, rather than as "conscious" or even "unwitting conformists" to rigid rules of conduct.

Others 16,17 highlight "neighborhood" as the social space where people go about their daily lives. For Bernard et. al. 16, in "neighborhoods" - viewed as "social capital" - a subjective feeling of belonging binds the network of residents together by strong obligations, affective ties of trust, and rules of reciprocity. Geographic proximity, structural/cultural barriers, and individual choices/preferences influence access to necessary life-saving medical resources. In Northeast Brazil, when access to oral rehydration solution is mystified, disallowing it for village mothers, feeble dehydrated babies die ${ }^{18}$. We argue that embedding individual illness experiences in macro-sociological contexts can cure biomedicine's social myopia.

This study situates childhood respiratory diseases within a particular "social space". Amidst grinding poverty, smoke-saturated air, and fecalladen waters, we describe how children fall ill and their caretakers strategize frantically to keep them alive. We unveil menacing metaphors that undermine the moral identity of "lowlanders" ("Baixada" residents), demoting them to the status of nonpersons ${ }^{19}$. We argue that promoting a "favorable environment" for health 20 in this waterlogged "cesspool" is an absurdity that poses a dire challenge for public health professionals. Reframing respiratory infections in a broader ecological framework 10,11,12,13 and deciphering the "eco-idiom of distress" may prevent childhood disease and death. This paper describes the experience of illness and the semantics of human suffering shaped by environmental determinants and (in turn) impacting the local ecology. The study was inspired by anthropologist Dr. Mark Nitcher's seminal article Idioms of Distress: Alternatives in the Expression of Psychosocial Distress: A Case Study from South India (1981) 21.

\section{Methods}

This qualitative study was conducted from January 2005 to November 2006 in the Dendê shantytown (pop. 20,210) situated on the polluted Cocó River in bustling Fortaleza, capital of Ceará. Forty years ago, armed residents invaded the abandoned plot, clashing with police. Land tenure was not legalized in Dendê until 1983. In recent years, a construction boom has fueled un- 
equal, haphazard, and mind-boggling growth in the surrounding area. A high wall separates the favela from the lush gardens of a private university, an upscale shopping mall, and a gargantuan Convention Center, the second largest in South America, with a seating capacity of 30,000 ! The university medical center provides free care, including home visits by student outreach workers (recently suspended by university authorities due to increased violence and safety concerns for students). No emergency services are available nearby; care must be sought at distant 24-hour hospitals.

Access by researchers to the Dendê neighborhood - notorious for drug trafficking, armed assaults, and gang wars 22 - was facilitated by community health workers who helped identify 22 key informants meeting one or more of the following criteria: (1) child caregiver; (2) professional child caregiver; (3) lay healer; and/ or (4) caregiver experience in treating respiratory problems. Six information-rich cases 23 of children who had fallen ill or died from respiratory illnesses were also identified and caretakers were interviewed. Open-ended questions were used to prompt informants' narrative responses: "Describe how respiratory (breathing) problems first appeared in the Dendê community?" "How does living here matter to your child's breathing problems?" "What do you think caused these problems?". Probing deeper, a guide with pre-determined topics oriented the interviews. Participant-observation of children and caregivers going about life-as-usual was conducted. The contents of historical documents and local health bulletins were reviewed.

All interviews were recorded, transcribed, and processed using the QSR N-Vivo program (QSR International Inc., Cambridge, USA). Text content was read exhaustively to identify emerging empirical themes including: abandonment, degrading metaphors, illness experience, environmental risk factors, and popular idioms of suffering. Analysis of six illness narratives was inspired by Bibeau \& Corin's "Signs, Meanings and Actions" and "contextualized semantic analysis" methodologies 24 . We aimed to capture caregivers' perceptions of symptoms, their attributed significance (if any), and therapeutic measures. The research project meets the ethical standards specified in Ruling n. 196/96 of the Brazilian Ministry of Health. Informants' anonymity was preserved.

\section{Results}

\section{A deadly social space: "The Lowlands" ("A Baixada")}

For our Brazilian informants, "place" matters. Nicknames in Portuguese attributed to the four residential enclaves within Dendê taint residents' moral character; the location of one's home corresponds to differing degrees of cultural and moral worth assigned to inhabitants. Residents of Rua do Comércio ("Commerce Street") are stereotyped as "wealthier", "better-educated", and "industrious entrepreneurs", although the terms do not apply to them all. The enclave "Bahia" is nicknamed after the predominantly African-Brazilian state whose population historically suffered from enslavement, racial prejudice, and social exclusion. "Rocinha", the third enclave, is nicknamed after one of the largest and most dangerous favelas in Rio de Janeiro's South Zone, often invaded by the military police in attempts to wrest control of the area from drug traffickers. And, finally, "a Baixada", - Alex and Gabriel's "place" - is the swampy low-lying "Lowlands"; it is home to the poorest of the poor. A sharp fundamental divide exists between the "higher-up" Commerce Street and the "lowest" "Lowlands"; the tightly-packed maze of haphazardly-constructed structures, in between, form the two intermediary enclaves.

Dendê's landscape reflects an underlying social structure of pronounced inequity. Neighborhood nicknames not only distinguish between environmental conditions, lifestyles, and social status of the four residential enclaves, but importantly, they reflect families' inequitable access to medical resources. Wealthier "higher-ups" on Commerce Street can walk or drive several blocks on a well-lit, busy paved road to the university medical complex, supermarkets, police station, and city bus stop. By sharp contrast, "lowlanders" are literally "stuck in the muck" (atolados na lama) of the soggy mangrove; they are mired in misery. The lack of electricity, running water, sewage disposal, and decent housing in "the Lowlands" denounces "the government's absolute neglect of poor people”. Raw sewage and trash are dumped into the river - the same contaminated water that residents store in the cisterns they construct near the riverbank and eventually drink. During the rainy season, the polluted river overflows, flooding homes. Downpours collapse the plastic tarp roofs donated by civil defense volunteers, and the makeshift mud-and-wattle structures crumble. Haphazard, illegal connections to the public electricity grid increase the risk of electrocution inside waterlogged homes. After lighting the damp kindling and charcoal in 
the clay stove, mothers vigorously fan the flame to cook a pot of beans, saving precious gas for warming the children's porridge. Trash is burned outside to "get rid of dirt". The air quickly "thickens" from the bellowing smoke. To earn money, fathers gather dry branches in the mangrove to burn in backyard kilns, producing charcoal to sell. By afternoon, the unbearable "smoky, hot and stuffy" house must be abandoned. Overworked mothers haul infants to relatives' homes located on "higher ground" - in search of a "cool breeze". Distraught parents must carry their sick children in their arms uphill on a dark narrow footpath winding through the muddy mangrove and past Bahia and Rocinha (risking physical assault, drunken weekend brawls, and stray bullets) before reaching "high ground" - and emergency medical care.

Lowlanders are also mired in the muck of stigma, prejudice, and social ostracism. Because they live on the polluted muddy riverbank together with crabs they dig to eat, "lowlanders" are stereotyped and stigmatized by the lofty "higher-ups" on Commerce Street as "filthy pigs [...] wallowing in stinking mud!". Their place, the soggy swamp, is pejoratively referred to as "a polluted pigsty”. A high wall marks the geographic boundaries of the imaginary "pigpen", fencing off lowlanders from the rest of Dendê and the surrounding affluent metropolitan area. Discriminated by place of residence and socially ostracized by class-based prejudice, a "Lowlands" woman complains: "People living elsewhere see the residents from the Lowlands as pigs. We are pigs! People don't value the ones living on the low side of the high wall!" Most disturbing is that she internalizes the debasing pig identity.

Despite being stigmatized as disgusting diseased "swine," "lowlanders" are frustratingly aware that life along the damp, polluted, and smoke-filled riverbed increases their children's health risks. Ironically, while pneumonia is more fatal for poor swamp-dwellers, the required treatment is devastatingly scarce. A 38-year-old single mother of four youngsters bemoans: "Pneumonia is a poor people's disease. In 'the Lowlands', we die from pneumonia! But the rich folks living higher up the hill on Commercial Street, they get sick and no big deal! You see, for rich people, there is always a remedy!" The two cases described below illustrate how "place" - and the moral reputation of its inhabitants - impacts children's risk of respiratory infection and, ultimately, death.
Social space and Alex's "crisis"

Harmful living conditions in the swampy "Lowlands" are blamed for 11-year-old Alex's "tired breathing" (cansaço) laments distraught mother Florinda, age 34. "Living in dampness" (morando no molhado), the five-member family crowds into a single-room dwelling that serves as kitchen in the morning, living room during the day, and bedroom at night. A charcoal kiln spews out clouds of dark suffocating "hot, burning smoke". The "thick, heavy air filled with clouds of hot smoke" is the "worst villain", causing Alex's respiratory problems. Florinda vigorously fans the air with a piece of cardboard to rid the house of smoke, but the stench impregnates the boy's hair, clothes, and hammock. White cotton sheets and diapers hung out to dry on the clothesline in the bright sunshine also reek of smoke. When Alex becomes unusually subdued, Florinda suspects he has inhaled dangerous "hot smoke": "Alex becomes withdrawn [...] has a hard time breathing, poor little thing! I already know he'll wake the next day with tired breathing". His fullblown "crises" (asthma attacks) are frightening: "He can hardly catch his breath [...] He cries out: 'Mommy, breathing makes my lungs hurt!' I tell him not to fight it! The more he panics, the more I fear he'll die!" One night he nearly did.

The couple rushed his limp body to an emergency room on a moonless night, risking the peril of traversing a footpath through feared gang "territory". Yet the doctor's diagnosis was dubious: "The doctors drew blood from head to foot but never discovered what he had! They said it was allergic asthma [...] but no proof!" Despite having only a third-grade education, Florinda proactively seeks information about her son's frequent colds, which she now steadfastly believes have "turned into" asthmatic bronchitis: "It's very dangerous! If it goes untreated, the person is never cured! It returns with more force to kill!" At the first sign of a cold, she prepares an herbal remedy to "loosen his mucous". She listens to his chest to check whether the "wheezing" (chiado no peito) has subsided: "With all that mucous inside, he sounds like a scratchy old loudspeaker!". As every mangrove mother knows, "when the cold and tired breathing turns into bronchitis", it spells death for poor people: "Rich people have treatment. But we're poor. People from the Lowlands don't dare catch bronchitis. If we catch bronchitis, we go straight to the cemetery!". Given the severity of Alex's "lung problem", Florinda now regularly consults a physician. Yet the lack of money (but not of her interest or effort) undermines the doctor's prescription: "The hospital gave me an aerosol 
machine. That helps! But it's expensive to buy the medicine and saline solution [...] It adds up! I can't afford it!". Sadly, to this day, Alex suffers severe bouts of bronchial asthma.

\section{Place and Gabriel's death from pneumonia}

The fact that "place" decides fate is dramatized by the tragic death of Gabriel, the first-born child of 27-year-old housewife Josefa, at age five from pneumonia. Her husband Carlos was unemployed during Josefa's pregnancy, forcing her to work long hours crocheting handicrafts in exchange for food: "I helped my mother-inlaw crochet and she bought food for me and my husband". Despite chronic hunger, Josefa delivered a baby boy without complications at 2AM on September 19, 2004, in a public hospital in Fortaleza. Observing the traditional month-long postpartum "resting-in" period, she was prohibited from "picking up a knitting needle" (a taboo). Since she was still famished, her abundant milk soon dried up and her full breasts withered. Determined to "sacrifice everything" to ensure their son's survival, she purchased powdered formula milk to feed the starving infant. By all neighbors' accounts, Josefa was a "caring mother".

One afternoon, Gabriel suddenly woke from his nap with a "cold", "a chest full of mucous", and "tired breathing”. Josefa monitored Gabriel's body temperature to prevent deadly thermal shocks: "I don't bathe him with water that's too hot or too cold when he has a cold! [...] It makes the mucous turn too thick [...]!". Yet his cold got worse and his chest filled with "mucous". He had a "high fever", "wet cough", and "short breath". Concerned, Josefa lit a fire in her wood stove, boiled water, and tossed in a handful of dry eucalyptus leaves. She bathed the boy in the menthol-scented water to "open up his chest and keep the mucous from sticking to the inside of his lungs". When the blazing sun set, Josefa carried him to a trustworthy healer, Dona Vicência, who suspected a "poorly cured cold" (gripe mal curada) and warned of the impending danger: "Sure, the herbal remedy cured his cold, but his lungs were still full of mucous! So when another cold comes, it will latch onto him even harder! Be careful, pneumonia is bronchitis' sister!". But she was soon back. The healer instructed her to take Gabriel to the hospital immediately: "I saw his labored breathing, the pain. So, I told her to run to the hospital right away! Pneumonia is a very serious problem! The boy needed to have a drain put in [...] and go straight to intensive care! Otherwise he would have been dead by the next day!". The doctors diagnosed him with pneumonia and hospitalized the boy for two weeks: "He was shaking all over... starting to have convulsions!". Josefa screamed desperately for help, but to no avail: "I was going mad that day! [...] begging for somebody to help [...] but they all turned a deaf ear!". When his fever broke and an X-ray showed his "lungs were clean and healed", the frail boy was quickly discharged. Within 24 hours, back home in the wet "Lowlands", his nagging symptoms reappeared. But now Josefa distrusted the hospital: "When he got sick again, I refused to take him to that hospital again!". Desperate, she quickly sold her broken refrigerator to purchase a bus ticket to another more distant hospital and checked her son in again. When Gabriel "vomited through the nose", she "panicked". Grasping her sacred rosary beads, she "prayed to Saint Francis of Assisi, begging him for a miracle!" Sadly, her prayers went unanswered. On March 10, 2005, her "baby" died. Neighborhood women congregated in the drafty damp home to comfort the grieving parents. Today she believes her "little angel" is "better off" in his "new home" - in heaven - sitting at Jesus' feet. In this sacred place, she rationalizes, Gabriel is able to "escape" forever the "harsh life" of the mangrove.

\section{The eco-idiom of distress in a mangrove}

Ecological context shapes the lived experience and semantics of misfortune suffered by mangrove families. This "eco-idiom of distress" describes the everyday trials and tribulations of childhood respiratory diseases in the context of urban poverty. Lay language expresses the depth of human sorrow in this particular place. Far from technical biomedical jargon, "lowlanders” speak a subjective language easily intelligible to mangrove neighbors. The vocabulary reflects sentiments, metaphors of stigma and social suffering from this common childhood killer. Ecological influences (e.g. fecal pollution, flooding, smoke, heat, thermal shocks, exposure to the elements, repulsive images) shape respiratory illness semantics and the experience of "lowlanders" submerged in the mangrove's fetid waters. Disgusting descriptors of pigs - nasty, feces-eating, diseased scavengers - are symbolically associated with swamp dwellers' personal images. Pejorative, degrading connotations of "swine" are transferred to "lowlanders" in three little letters: P-I-G. Through word plays and double meanings, moral value is then assigned to the pig's image. Traits of the "contemptible swine" and over-sexed, partner-swapping "shameless" hog metaphorically transfigure lowlanders' personae, despoiling their moral reputation. They are demoted to the status of nonpersons - to pig-people. 
The hazards of an imbalance between man and nature are also encoded in the mangrove's eco-idiom. Swamp-dwellers use the phase "living in dampness" to describe the daily drudgery of raising sickly children amidst leaky roofs, flooded packed-earth floors, soggy mattresses, and damp diapers that never dry out. They articulate the dangers of "living a suffocated life" (vida sufocada) with "thick", "heavy", "hot", "burning smoke" bellowing out of backyard kilns and suffocating their children. They verbalize the hidden danger of a seemingly simple "poorly treated cold" that recurs with a vengeance as pneumonia to kill frail, malnourished bodies. And it tells of the frustration of being "stuck in the muck" (atolado na lama) or literally "bogged-down" in poverty, unable to implode the structural constraints that limit opportunity. At the same time, the mangrove's eco-idiom also speaks of the need to "balance" or "harmonize" man and nature to promote healthy living despite harsh realities. Residents assign temperatures/climatic conditions to risk factors ("cold breeze", "hot burning smoke", "hot dust", "hot rain", "dangerously hot breast milk") and respiratory symptoms ("dry and wet coughs", "cold lung mucous", "intestinal heat", "hot blood") that follow their "eco-logic" in opposition to quality medicines ("cold mint tea", "cool manioc paste", etc.). Extreme temperatures and thermal shocks must be avoided in order to preserve children's health.

\section{Discussion: place, pneumonia, and "pig-people"}

This ecological interpretation $10,11,12,13$ of childhood respiratory diseases in Northeast Brazil reconciles subjective individual experience (that of Alex and Gabriel) with influences of external socio-environmental forces. The unity of human experience is held intact, not fragmented as disease-focused studies typically do. Our holistic approach connects persons with "place". Local worlds of pain, suffering, and grief 9 are situated on the margins of a grossly inequitable, modernizing city. Rather than juxtapose individual and society as two separate entities - one external to the other - in the Lowlands we witness a "relationality" between illness experience and place - parts of the same social reality. Bourdieu's theoretical constructs of "social spaces", "habitus", and "symbolic power" 14,15; the notion of "neighborhoods" in Bernard et. al. 16; and Kleinman's concept of "local moral worlds" 9 helped us reframe, amplify, and contextualize an otherwise myopic biomedical focus. Surprisingly, these heuristic devices captured the stratified and desperate cultural and moral landscape in Dendê.
In a study similar to ours, Tianshu 25 describes how linguistic devices are strategically appropriated by local residents in Shanghai, China, to demarcate cultural and moral boundaries between the city's upper and lower quarters. Although geographic boundaries were largely removed during the Maoist era, telltale symbolic indicators of residents' moral worth remained firmly intact. In today's popular imagination, the upper quarters symbolize modernity and civilization, while the lower quarters, situated just beyond the city's neon lights, exemplify backwardness and moral inferiority. The dichotomy between "upper and lower quarters" in post-reform Shanghai is remarkably similar to the Commercial Street's "higher-ups" and "lowlanders" that we describe in Fortaleza. The American Heritage Dictionary of the English Language (sub verbo "lowland"; "lowlifes") defines "lowlands" in a strict geographical sense as "land that is low or level in comparison with the adjacent country". But it also means "a location having or suited for a low rank or position [...] a humble, plain, simple or undistinguished spot". The inhabitants of the "the Lowlands" are thus "lowlifes" or "disreputable and degenerate persons". Tianshu 25 argues that emic notions of locality-based citizenship encode conditions of race and class relations. Moreover, such notions can be utilized as a "disparity index" to measure the social and moral distance between the powerful and the marginal. We concur.

Contrary to the tendency in Bernard et al. 16 to see neighborhoods as spaces of "belonging" and cooperative bonding, in the poor Dendê slum we witnessed internal differentiation, hierarchical structuring, class-based prejudice, and physical ostracism. Perhaps given the socio-economically desperate society of Northeast Brazil, we found Bourdieu's 14,15 concept of "symbolic violence" a more fitting lens through which to view the human health condition. In this context, symbolic power, Bourdieu argues, is "worldmaking power," for it involves the capacity to impose the "legitimate vision of the social world and its divisions" (p. 89) 14. Symbolic power functions to differentiate and legitimize unequal and hierarchical arrangements among localities - Commercial Street, Bahia, Rocinha, and the Lowlands - within Dendê. Moreover, says Bourdieu, these cognitive distinctions also generate forms, to include symbols of in-grouping and out-grouping. Symbolic classifications become expressions of social hierarchy, giving meaningful order to the social world 14,15. However, power is not in words or symbols per se but in the "belief in the legitimacy of the words and of who utters them". Bourdieu stresses how the dominated must accept (as 
legitimate) their own condition of domination; it requires consent by both parties, the dominant and the dominated 14,15 . Our results emphasize how the discourse of lowlanders is internalized, legitimating their collective status as poor, pigs, and nonpersons. Their words resonate with selfdeprecation: "Pneumonia is a poor people's disease. In the Lowlands, we die from pneumonia!". Here, the legitimate opinion is that pneumonia is an infection of the impoverished. Since "we" die from this infection of inequity 26 , "we" are necessarily "poor". Meanwhile, "There's treatment for rich people. We are poor. People from the Lowlands don't dare catch bronchitis. If we catch bronchitis, we go straight to the cemetery!". Again, our Lowland informant legitimates her inferior position and forfeits her right to demand equal access to treatment. Even the highly stigmatized "pig" identity is internalized: "People living elsewhere see the residents from the Lowland as pigs. We are pigs! People don't value the ones living on the low side of the high wall!". We agree with Bourdieu that legitimation is the cement of inequitable class relations in Dendê 14,15 .

Intriguingly, deciphering the eco-idiom of distress sheds light on the subtle (albeit perverse) stigma and social exclusion. The semantics of suffering by "pig-people" reveal the cultural construction of non-personhood 21. How exactly do the "higher-up" Dendê residents despoil (subliminally, unconsciously, or even unwittingly) the moral reputation of "lowlanders", condemning them to a social death 27,28 ? How do they impute disgracing and disempowering imagery? To begin, one must ask: Why a pig? Although pigs are known to be intelligent 29, they are considered one of the filthiest, most immoral, and most diseased animals on earth 29 . Pork is saturated with a long list of negative, defiling, and nasty connotations. Pigs are aggressive omnivorous scavengers that eat insects, worms, rotting carcasses, garbage, and their own and human excrement. Pigs are so adept at devouring human feces that in rural China "pig toilets" 29 deliver excrement from the privy through a chute and hole in the latrine's floor directly to the pigsty to be eaten fresh by the awaiting swine. As if that were not sufficiently disgusting, pigs use their snouts to root in the mud and then wallow in their own urine and feces. Little wonder that the slang word in Portuguese, "chiqueiro" or "pigsty" is used to describe a flagrantly messy and filthy teenager's room, for example. Pigs and humans share serious zoonotic infections such as trichinosis, porcine neurocysticercosis, and (ironically) respiratory infections like mycoplasmal pneumonia of swine and the feared swine flu. In 2009, pigs spread the H1N1 influenza virus across the globe, killing thousands 30 . Moreover, swine have shady reputations as shameless oversexed animals that engage in sex for pure pleasure and reproduce rapidly 29 . And another slang term in Portuguese, "porcaria", derived from the word "porco" or pig, signifies that whatever one is referring to "isn't worth a piece of shit". In this light, pigs have recently gained a political connotation in Brazil, highlighting their purportedly shady, fraudulent, and immoral character. An expression popularized by the liberal Brazilian journalist Paulo Henrique Amorim, in his political blog Conversa Afiada (Sharp Tongue - http:// www.conversaafiada.com.br/), "PiG" stands for "O Partido da Imprensa Golpista". The sarcastic logotype of PiG is a caricature of a tank-maneuvering aggressive hog with devilish features (Figure 1) - a tongue-in-cheek criticism of media mongrels and overbearing journalists who unethically dominate and manipulate public opinion, plotting to usurp citizens' democratic constitutional right to freedom of the press. Is it any wonder that our informants avoid pigs or pork? In Northeast Brazil, pork is thought to be "reimosa" (polluting the blood); it is strictly

Figure 1

Pigs' images have been culturally-encoded with infinite connotations and meanings, many derogatory. Sarcastic caricature by Carlos Latuff of an unethical "devilish" pig media mongrel and symbol of PiG, "O Partido da Imprensa Golpista", popularized by Paulo Henrique Amorim's political blog "Conversa Afiada".

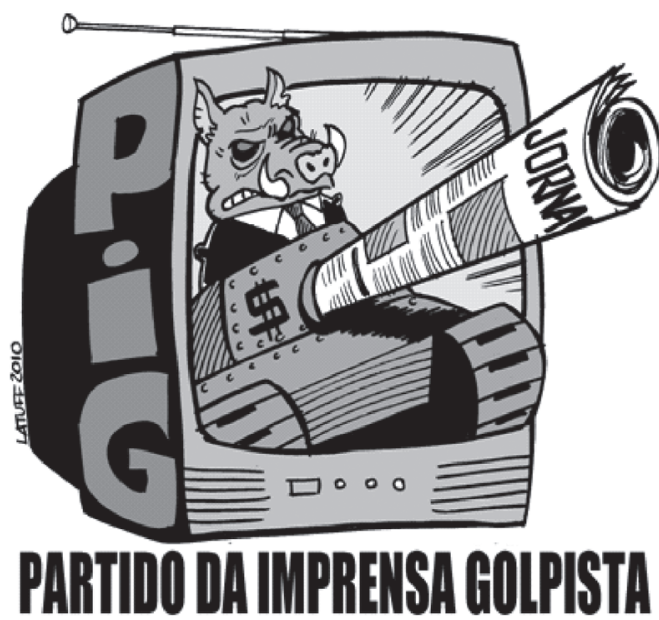

Source: Carlos Latuff. http://pt.wikipedia.org/wiki/

Ficheiro:PIG-free_reproduction.gif (accessed on

15/Sep/2012). 
taboo for women during menstruation and the postpartum" resting-in" period ${ }^{19}$. Islamic, Muslim, and Jewish cultures 31 also restrict or forbid pork. The Qur'an [5:3] says: "Forbidden to you (for food) are: dead meat, blood, the flesh of swine, and that on which hath been invoked the name of other than Allah". And the Bible, in the book of Leviticus [11:7-8], warns: "And the swine, though he divide the hoof, and be cloven footed, yet he chews not the cud; he is unclean to you [...] Of their flesh you shall not eat, and their carcass you shall not touch, they are unclean to you". Contact with swine should be avoided.

Metaphorically speaking, what is said of pigs is true of "lowlanders". In Metaphors We Live By, Lakoff \& Johnson 32 (p. 5) state: "The essence of metaphor is understanding and experiencing one kind of thing in terms of another". This is possible because the metaphor is built into the conceptual system of the culture in which we live; it is embedded in our values, perceptions, and systems of meaning. When a direct association between two domains is too abstract, unclear, difficult, or even risky, for whatever reason, metaphors are used to define and assign meaning, thus giving us a new understanding of our experience. By highlighting certain "animalistic" traits of "lowlanders", while subjugating human characteristics, others come to "see" lowlanders living in damp drafty housing with little to eat as nonpersons possessing pig-like traits. Thus, when swamp-dwellers dig crabs out of feces-laced mud with their bare hands to feed their hungry children, "higher-ups" "see" pigs rooting out food in the filth with their snouts. When lowlanders' homes are flooded by the polluted Cocó River - where Fortaleza residents flush their fecal waste - they "see" a massive open-air "pig latrine". When a fence or wall is erected near the swampy land, they "see" a pigsty to corral and pen in nasty aggressive hogs, separating them from humans. When a single mother of five becomes pregnant with her sixth child, they "see" an immoral, irresponsible sow having another litter. When they get accidently short-changed by a lowlander selling charcoal they "see" shady dishonest "swine". Rather than expressing solidarity, "higher-ups" keep lowlanders at a distance, avoiding any possible contact with defiling, diseased, and immoral "pig-people". Unconsciously, they fear contracting swine pneumonia, swine flu, or a myriad of other diseases from infected lowlanders like Alex and Gabriel, the sickly "piglets".

Such animalization - or the symbolic transfiguration of living, breathing human beings into beasts for slaughter - was one of "the crimes of dehumanization" 33 practiced by Nazis in WWII
German death camps. Jewish prisoners were herded into train cars like cattle, annihilating their personal identities before murdering them. Nations \& Monte ${ }^{34}$, expanding on theories of stigma by Goffman 27 and Douglas 28 , described how being infected with Vibrio cholera - the "dog's disease" - undermined the personhood of the infected in a nearby Fortaleza slum; their personal images were metaphorically linked with the popular term "vira-latas" - meaning both "stray mutts" and "prostitutes", blighting their moral reputation. As we have seen, stigmatization is polysemous, bridging individual subjectivity, social interactions, societal structures, preexisting cultural images, ingrained racial stereotypes/ class prejudices, and (we add) ecological context.

Our results also corroborate Bourdieu 14,15 in casting citizens as clever "strategists". Mangrove parents maneuver through a maze of environmental risks, proactively seeking treatment - from herbal remedies to hospital care - to relieve "tired breathing" and pneumonia. They weigh ecological risk (i.e. fecal contamination, smoke inhalation, gang assaults) against pressing demands for food, economic survival, and medical care. Only by comprehending people's "eco-logic" or ecology of decision-making can health professionals avoid blaming victims 35 for practices which on the surface appear to aggravate children's health.

Finally the eco-idiom of distress speaks of an equilibrium theory of health contesting hegemonic biomedical discourse. We confirmed that informants' therapeutic rationality is guided by an attenuated form of Greek humoral pathology, based on the Principle of Opposition described by Hippocrates and found today throughout Spanish and Portuguese America 36. Given renewed interest in health ecology $10,11,12,13$, revisiting this equilibrium model is noted but (regrettably) beyond the scope of this paper.

\section{Conclusion}

Given the immensity of environmental degradation, the depth of human suffering, and the perverseness of stigmata in this Brazilian mangrove community, biomedical interventions (e.g. aerosol, antibiotics, drainage tubes, etc.) appear powerless to promote "favorable environments" 18. Sweeping social change is needed. Although keenly aware that environmental risk undermines children's health, the "lowlanders" remain both "mired in the muck" of dehumanizing stigma and voiceless to confront structural/ symbolic violence. Yet to combat "infections of 
inequities" 26 it is critical to build a sustainable, egalitarian, and socially just society. As Brazilian activist Paulo Freire 37 reminds us, all citizens the oppressed and illiterate included - must be empowered with a voice and become engaged in the political process to transform our world.
When infected residents are degraded to nonpersons - to "filthy, promiscuous, and diseased pigs" - our most formidable tasks to control childhood respiratory infections must be to reduce ecological risk, challenge class-based prejudice, and restore human dignity.

\section{Resumen}

Situado en el neo-democrático globalizado Nordeste brasileño, este estudio antropológico analiza el papel del contexto ecológico en el encuadramiento para experimentar y expresar la miseria humana. Entrevistas etnográficas, narrativas y un "análisis semántico contextualizado" revelan la experiencia vivida a causa de enfermedades respiratorias infantiles en 22 residentes de manglares urbanos. Los informantes hablan en un "eco-lenguaje de incomodidad respiratoria", basado en una "eco-lógica" popular, reflejando la dura realidad de "vivir en la humedad, en el manglar." Residentes de áreas elevadas legitiman sus sentimientos de superioridad, estigmatizando los residentes en la "Baixada" como un tabú, como enfermos (cisticercosis porcina, gripe porcina, etc.), como "cerdos inmundos, atrapados en el fango". Animalizando las identidades de sus habitantes, despreciándolos a la categoría de no-personas. Además de infecciones, los niños sufren barreras sociales derivadas del ostracismo, estigma y falta de acceso a los cuidados médicos. Promover un "ambiente favorable" requiere la reducción del riesgo ecológico, enfrentando los prejuicios clasistas y restaurando la dignidad humana.

Antropología Médica; Enfermedades Respiratorias; Ecología

\section{Contributors}

M. Nations participated in the research design and literature review. She conducted the semantic interpretation of data and wrote the text. A. P. S. Gondim designed the project, coordinated data collection, analyzed data and revised the text.

\section{Acknowledgments}

Editing suggestions by Kenneth Martin greatly improved the text. M. Nations received support from CNPq (Scientific Productivity Award).

\section{References}

1. Amorim DG, Adam T, Amaral JJF, Gouws E, Bryce J, Victora CG. Integrated management of childhood illness: efficiency of primary health in Northeast Brazil. Rev Saúde Pública 2008; 42:183-90.

2. Lanata C. Incidência e evolução da pneumonia em crianças a nível comunitário. Washington DC: Pan American Health Organization; 2003.

3. Centro de Treinamento em Desenvolvimento Econômico Regional. A expansão da periferia urbana de Fortaleza e seu efeito de segregação e deteorização da qualidade de vida da população. Fortaleza: Prefeitura Municipal de Fortaleza; 1981.

4. Hoerning JA. A questão da habitação em Fortaleza. In: Encontro prática e diálogo, 2005, Fortaleza. Informativo. Fortaleza: Fundação Konrad Adenauer; 2005. p. 1-8.

5. World Health Organization. Does shortening the training on integrated management of childhood illness guidelines reduce effectiveness? Results of a systematic review. Geneva: World Health Organization; 2008.

6. Capra F. The turning point: science, society, and the rising culture. New York: Bantam Books; 1983.

7. Biglan A. Contextualism and the development of effective prevention practices. Prev Sci 2004; 5:15-21.

8. Lawrence C, Weisz G. Greater than the parts: holism in biomedicine 1920-1950. New York: Oxford University Press; 1998.

9. Kleinman A. What really matters: living a moral life amidst uncertainty and danger. Oxford: Oxford Press; 2006.

10. Dubos R. Mirage of health. Garden City: Doubleday-Anchor; 1959.

11. Stineman MG, Streim JE. The biopsycho-ecological paradigm: a foundational theory for medicine. PM R 2010; 2:1035-45.

12. Panter-Brick C, Clarke SE, Lomas H, Pinder M, Lindsay SW. Culturally compelling strategies for behavior change: a social ecology model and case study in malaria prevention. Soc Sci Med 2006; 62:2810-25. 
13. Okamoto SK, LeCroy CW, Tann SS, Rayle AD, Kulis S, Dustman P, et al. The implications of ecologically-based assessment for primary prevention with indigenous youth populations. J Prim Prev 2006; 27:155-70.

14. Swartz D. Culture \& power: the sociology of Pierre Bourdieu. Chicago: University of Chicago Press; 1997.

15. Bourdieu P. Language and symbolic power. Cambridge: Harvard University Press; 1991.

16. Bernard P, Charafeddinea R, Frohlich KL, Daniela M, Kestensa Y, Potvin L. Health inequalities and place: a theoretical conception of neighbourhood. Soc Sci Med 2007; 65:1839-52.

17. Frohlich KL, Potvin L, Chabot P, Corin E. A theoretical and empirical analysis of context: neighbourhoods, smoking and youth. Soc Sci Med 2002; 54:1401-17.

18. Nations M, Rebhun L. Mystification of a simple solution: oral rehydration therapy in Northeast, Brazil. Soc Sci Med 1988; 27:25-38.

19. Kleinman A, Yunxiang Y, Jun J, Lee S, Zhang E, Tianshu P, et al. "Deep China": the moral life of the person (what anthropology and psychiatry tell us about China today). Berkeley: University of California Press; 2011.

20. World Health Organization. The Ottawa charter for health promotion. Geneva: World Health Organization; 1986.

21. Nitcher M. Idioms of distress: alternatives in the expression of psychosocial distress: a case study from South India. Cult Med Psychiatry 1981; 5:379-408.

22. Pordeus AMJ, Farias FSAB, Oliveira ER, Moreira TP Comunidade do Dendê: um diagnóstico de suas famílias. Revista do Centro de Ciências da Saúde 1999; 1:9-17.

23. Yin RK. Case study research: design and methods. $4^{\text {th }}$ Ed. Los Angeles: Sage Publications; 2009.

24. Bibeau G, Corin E. From submission to the text to interpretative violence. In: Bibeau G, Corin E, editors. Beyond textuality: asceticism and violence in anthropological interpretation. Approaches to semiotics series. Berlin: Mounton de Gruyter; 1994. p. 3-54.
25. Tianshu P. Place attachment, communal memory, and the moral underpinnings of gentrification in post-reform Shanghai. In: Kleinman A, Yunxiang Y, Jun J, Lee S, Zhang E, Tianshu P, et al., editors. "Deep China": the moral life of the person (what anthropology and psychiatry tell us about China today). Berkeley: University of California Press; 2011. p. 152-76.

26. Farmer P. Infections and inequalities: the modern plagues. Berkeley: University of California Press; 1999.

27. Goffman I. Stigma: notes on the management of soiled identity. Englewood Cliffs: Prentice-Hall; 1963.

28. Douglas M. Purity and danger. London: Routledge \& Kegan Paul; 1966.

29. Nelson SM. Ancestors for the pigs: pigs in prehistory. Philadelphia: Museum of Applied Science Center for Archaeology, University of Pennsylvania; 1998.

30. Farez S, Morley RS. Potential animal health hazards of pork and pork products. Rev Sci Tech 1997; 16:65-78.

31. Lobban Jr. RA. Pigs and their prohibition. Int J Middle East Stud 1994; 26:57-75.

32. Lakoff G, Johnson M. Metaphors we live by. Chicago: University of Chicago Press; 1990.

33. Becker A. Extermínios: o corpo e os campos de concentração. In: Courbin A, Courtine JJ, Vigarello G, editors. História do corpo. Petrópolis: Editora Vozes; 2008. p. 417-41.

34. Nations MK, Monte CMG. "I'm not dog, no!": cries of resistance against cholera control campaigns. Soc Sci Med 1996; 43:1007-24.

35. Ryan W. Blaming the victim. New York: Vintage Press; 1971.

36. Foster GM. On the origin of humoral medicine in Latin America. Med Anthropol Q 1987; 1:355-93.

37. Freire P. Pedagogy of the oppressed. New York: Seabury Press; 1970.

Submitted on 29/Feb/2012

Final version resubmitted on 14/Sep/2012 Approved on 19/Sep/2012 